\title{
Anatomical characters of the medicinal leaf and stem of Gymnanthemum amygdalinum (Delile) Sch.Bip. ex Walp. (Asteraceae)
}

\author{
Márcia do Rocio Duarte*, Ariane Gonçalves Silva
}

\author{
Laboratory of Pharmacognosy, Department of Pharmacy, Federal University of Paraná, Curitiba, Paraná, Brazil
}

\begin{abstract}
Gymnanthemum amygdalinum (Delile) Sch.Bip. ex Walp. (Asteraceae), better known by its former name Vernonia amygdalina Delile, is a small shrub used in folk medicine as an antipyretic, laxative, antimalarial and anthelmintic. Studies have demonstrated that different vegetal extracts possess antioxidant, antimicrobial and antiparasitic activities. Among the bioactive metabolites, there are sesquiterpene lactones, saponins, polyphenols and flavonoids. This study investigated the leaf and stem microscopic characters of $G$. amygdalinum, aiming to expand the knowledge on this medicinal species and indicate anatomical structures. Plant material was fixed and sectioned by freehand and using a microtome. The sections were either stained or underwent standard histochemical tests. Scanning electron microscopy was performed to investigate epidermal relief. The leaf is amphistomatic with anomocytic stomata. There are striate cuticle, glandular and non-glandular trichomes and dorsiventral mesophyll. In transverse section, the midrib and the petiole have a plano-convex shape. Both show several collateral vascular bundles and few crystals of calcium oxalate. In the stem, the epidermis persists and the phellogen has a peripheral origin. It presents typical endodermis and sclerenchymatic caps adjoining the phloem. The aspects that contribute to characterizing the species are stomata on both leaf surfaces, midrib and petiole features, the endodermis and sclerenchymatic caps in the stem, as well as the different types of trichome on both aerial organs.
\end{abstract}

Uniterms: Gymnanthemum amygdalinum/pharmacognosy. Gymnanthemum amygdalinum/ microscopic characterization. Vernonia amygdalina/pharmacognosy. Vernonia amygdalina/microscopic characterization. Asteraceae/pharmacognosy. Medicinal plants.

Gymnanthemum amygdalinum (Delile) Sch.Bip. ex Walp. (Asteraceae), espécie mais conhecida pela sinonímia Vernonia amygdalina Delile, é um pequeno arbusto empregado na medicina popular como antipirético, laxativo, antimalárico e anti-helmíntico. Estudos demonstraram que diferentes extratos do vegetal possuem atividades antioxidante, antimicrobiana e antiparasitária. Entre os metabólitos bioativos presentes, citam-se lactonas sesquiterpenoides, saponinas, polifenóis e flavonoides. Este estudo investigou os caracteres microscópicos de folha e caule de G. amygdalinum, a fim de ampliar o conhecimento acerca dessa espécie medicinal e apontar estruturas anatômicas características. O material foi fixado e seccionado à mão livre e em micrótomo. Os cortes foram corados ou submetidos aos testes histoquímicos clássicos. Empregou-se microscopia eletrônica de varredura para investigar a ultraestrutura da superfície epidérmica. A folha é anfiestomática com estômatos anomocíticos. Há cutícula estriada, tricomas glandular e tector e mesofilo dorsiventral. Em secção transversal, a nervura central e o pecíolo têm contorno planoconvexo. Ambos mostram vários feixes vasculares colaterais e poucos cristais de oxalato de cálcio. No caule, a epiderme permanece e o felogênio tem instalação periférica. São observadas endoderme típica e calotas esclerenquimáticas apostas ao floema. Os aspectos que fornecem elementos para a identificação da espécie são a ocorrência de estômatos em ambas as superfícies foliares, a organização da nervura central e do pecíolo, a endoderme e as calotas esclerenquimáticas no caule, além dos diferentes tipos de tricoma nos órgãos aéreos estudados.

Unitermos: Gymnanthemum amygdalinum/farmacognosia. Gymnanthemum amygdalinum/caracterização microscópica. Vernonia amygdalina/farmacognosia. Vernonia amygdalina/caracterização microscópica. Asteraceae/farmacognosia. Plantas medicinais.

*Correspondence: M. R. Duarte. Departamento de Farmácia, Setor de Ciências da Saúde, Universidade Federal do Paraná. Av. Pref. Lothário Meissner, 632 Jardim Botânico, 80210-170 - Curitiba - PR, Brasil. E-mail: marciard@ufpr.br 


\section{INTRODUCTION}

Gymnanthemum amygdalinum (Delile) Sch.Bip. ex Walp. (Asteraceae), formerly known as Vernonia amygdalina Delile, is a small shrub commonly called bitterleaf due to its peculiar taste (Momoh et al., 2012). In Brazil, this species is referred to as alumã, boldo or alcachofra (Agra et al., 2008; Coelho-Ferreira, 2009; Almeida et al., 2012). It has an erect stem covered with white hairs, ovate-lanceolate to elliptic-lanceolate leaves with short petiole, and creamy-white inflorescences (Achigan-Dako et al., 2009). The plant may grow up to 3 $\mathrm{m}$ high in tropical regions and is reputed to have several health benefits (Farombi, Owoeye, 2011).

In folk medicine, the aerial organs of G. amygdalinum are mainly used as an antipyretic, laxative, antimalarial and anthelmintic (Igile et al., 1994; Vigneron et al., 2005; Agra et al., 2008; Georgewill, Georgewill, 2010). Studies of different extracts have shown antioxidant (Igile et al., 1994; Farombi, Owoeye, 2011), antimicrobial (Erasto, Grierson, Afolayan, 2006; Okigbo, Mmeka, 2008), antiparasitic (Tadesse et al., 1993; Ademola, Eloff, 2011; Adiukwu, Amon, Nambatya, 2011), antidiabetic (Akinola et al., 2011; Ong et al., 2011) and antihypertensive (Ajibola, Eleyinmi, Aluko, 2011; Saliu et al., 2011) properties.

Chemical analysis of the leaf and stem found different groups of metabolites, such as sesquiterpene lactones (Babalola, Anetor, Adeniyi, 2001; Erasto, Grierson, Afolayan, 2006; Luo et al., 2011), saponins (Adiukwu, Amon, Nambatya, 2011), polyphenols (Ong et al., 2011; Saliu et al., 2011) and flavonoids (Igile et al., 1994; Atangwho et al., 2009).

Although there are various reports on bioactive compounds and pharmacological activities of the species, there is a paucity of information on its anatomical features. Therefore, this study was designed to investigate the leaf and stem microscopic characters of G. amygdalinum and contribute to the knowledge on this medicinal plant indicating anatomical structures for its identification.

\section{MATERIAL AND METHODS}

\section{Plant material}

Specimen samples of Gymnanthemum amygdalinum (Delile) Sch.Bip. ex Walp. (Asteraceae) were collected from the spontaneous flora in Palotina, state of Paraná, Brazil (coordinates $24^{\circ} 17^{\prime} \mathrm{S}$ and $53^{\circ} 40^{\prime} \mathrm{W}$, and altitude of $290 \mathrm{~m}$ ), in February 2005. The species was identified by the herbarium curator Osmar dos Santos Ribas at the
Museu Botânico Municipal de Curitiba where a voucher is registered as MBM 301457.

\section{Methods}

Fully-developed leaves and stems, obtained 5-30 $\mathrm{cm}$ from the shoot, were chemically fixed in FAA70 (Johansen, 1940) and preserved in 70\% (v/v) ethanol solution (Berlyn, Miksche, 1976).

For anatomical investigation, the leaves (lower third part) and young stems were prepared according to the standard techniques for light microscopy, including histochemical tests, and scanning electron examination. Semipermanent slides were prepared with the freehand transverse and longitudinal sections of the fixed material. These sections were stained with astra blue and basic fuchsine (Roeser, 1972). For permanent slides, the material was embedded in glycol-methacrylate, sectioned using a rotary microtome and stained with toluidine blue (O'Brien, Feder, McCully, 1964).

In order to reveal the cell content and cell wall impregnation, histochemical tests were done with Sudan III for lipophilic substances (Sass, 1951), ferric chloride for phenolic compounds (Johansen, 1940), lugol for starch grains (Berlyn, Miksche, 1976), hydrochloric phloroglucin for lignin (Foster, 1949), and a diluted solution of sulphuric acid for calcium crystals (Oliveira, Akisue, 1997).

For scanning electron microscopy, the fixed fragments were dehydrated in a graded ethanol series and by carbon dioxide critical point drying, gold coated and observed in a high vacuum (Souza, 1998).

\section{RESULTS}

The leaf presents glandular and non-glandular trichomes on both epidermal surfaces. The glandular trichomes (Figures 1A, 1B, 1E, 2C, 3B) are capitate, with a bicellular head and short pedicel, located in a small epidermal depression. The non-glandular trichomes (Figures 1A, 1D) are comparatively more abundant. They are long, multicellular and uniseriate, having about 5-15 cells and an elongated apical cell. An evident striate cuticle coats the epidermis (Figures 1B, 1C). In face view, the epidermal cells are wavy on the adaxial side (Figure 1F) and sinuous on the abaxial surface (Figure 1G). There are anomocytic stomata on both sides (Figures 1F, 1G).

In transverse section, the epidermis is uniseriate and the stomata are inserted at the same level as, or slightly above, the surrounding cells, and show external cuticular ledges (Figure 2A). The mesophyll is dorsiventral, usually encompassing one layer of palisade parenchyma and five 

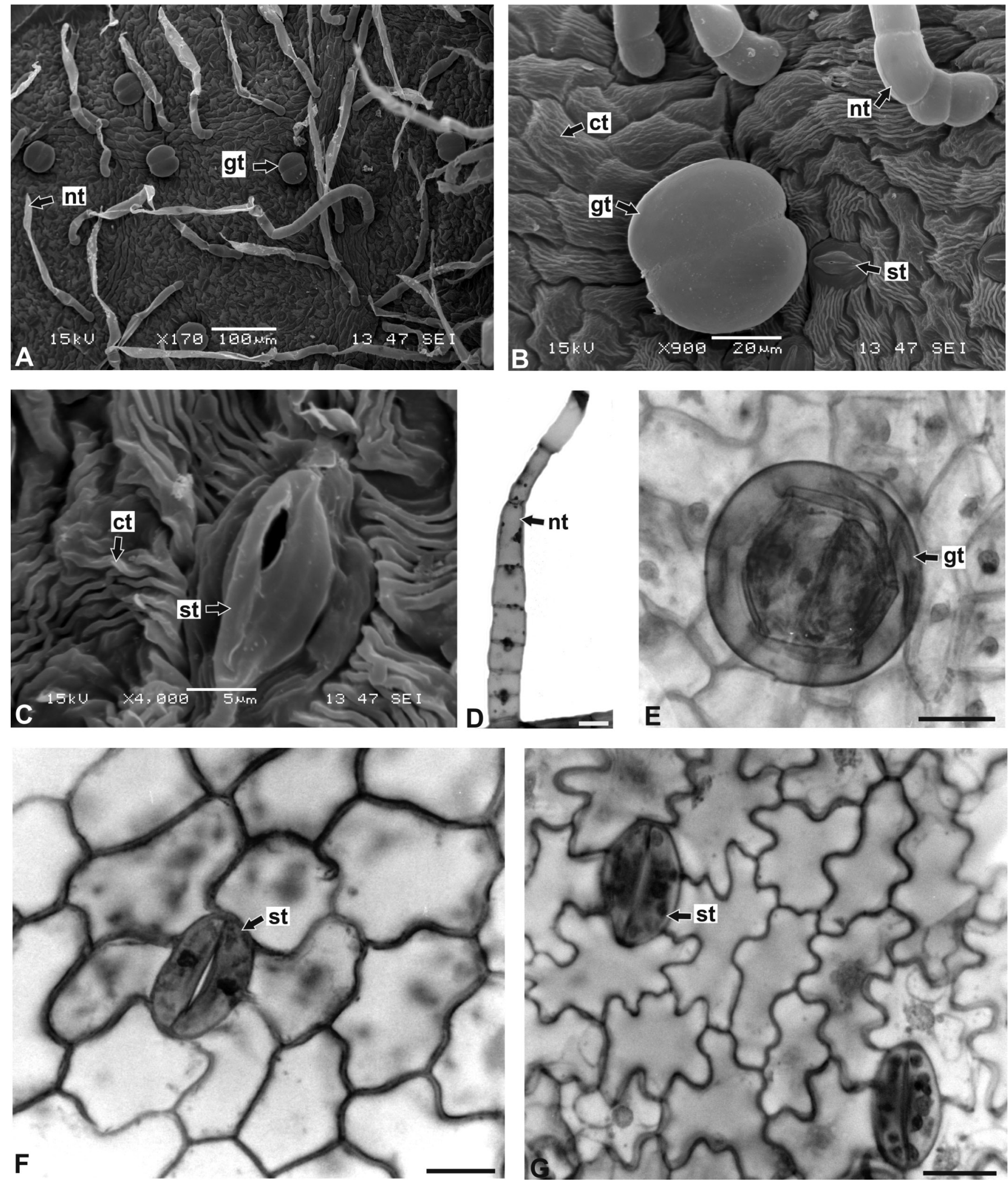

FIGURE 1 - A-G: Gymnanthemum amygdalinum (Delile) Sch.Bip. ex Walp. - leaf: A-C. Detail of non-glandular and glandular trichomes, stomata and striate cuticle under SEM; D. Medium and basal portion of a non-glandular trichome; E. Capitate glandular trichome; F, G. Adaxial and abaxial epidermal surfaces, respectively. Abbreviations: ct - cuticle, gt - glandular trichome, nt - nonglandular trichome, SEM - scanning electron microscopy, st - stomatum. Bar $=20 \mu \mathrm{m}(\mathrm{D}-\mathrm{G})$. 
to seven rows of spongy parenchyma. Minor collateral bundles are distributed in the chlorenchyma and encircled by a parenchymatic sheath (Figure 2A).

The midrib and petiole are alike. Both have a plano-convex shape, in transverse section (Figures 2B,
3A). Below the uniseriate epidermis, a strand of angular collenchyma is evident (Figures 2C, 2E, 3B) and, traversing the ground parenchyma, several collateral vascular bundles with cambial zone (Figures 2E, 3C) are arranged in an open arc (Figures 2B, 3A). A few crystals
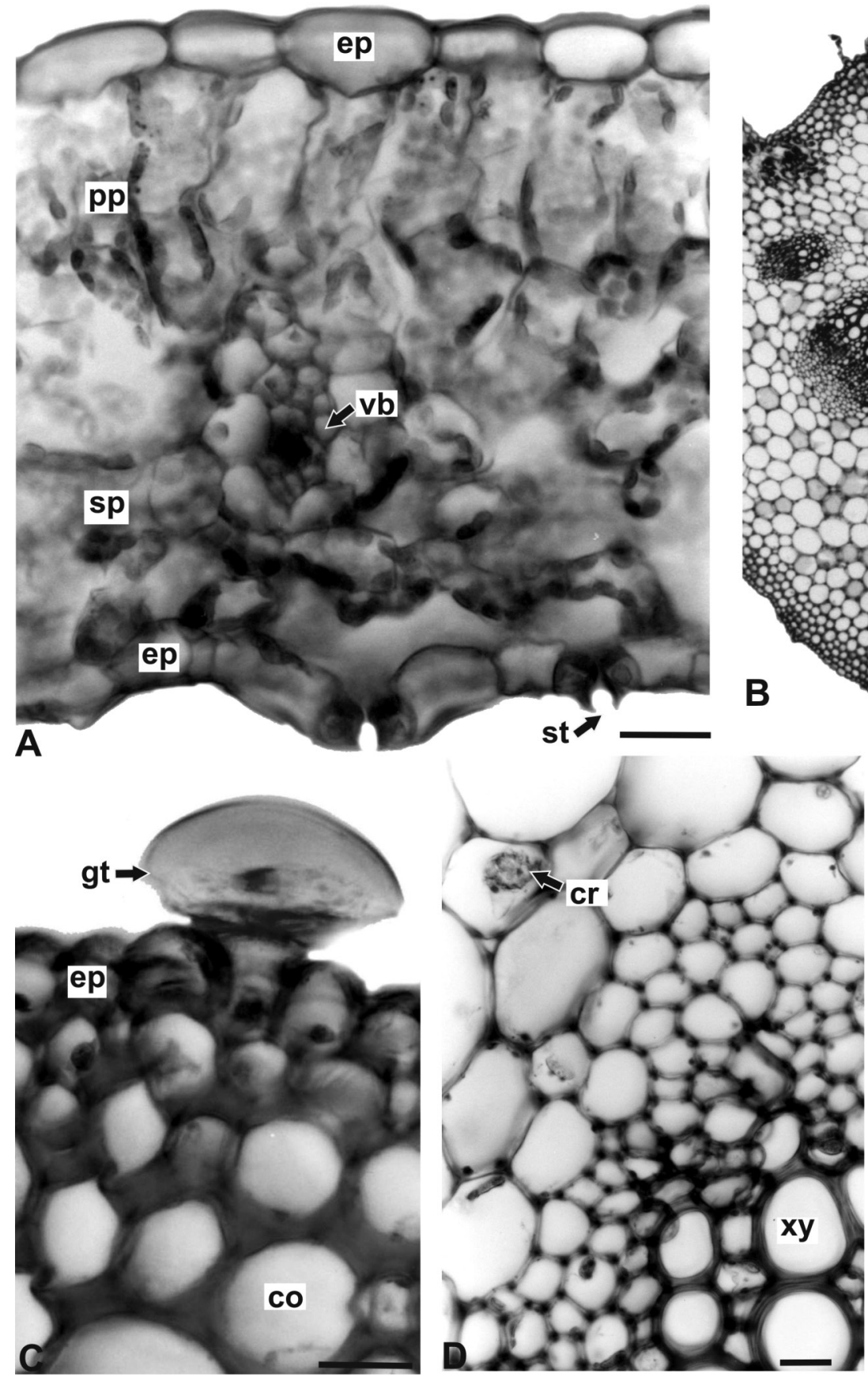
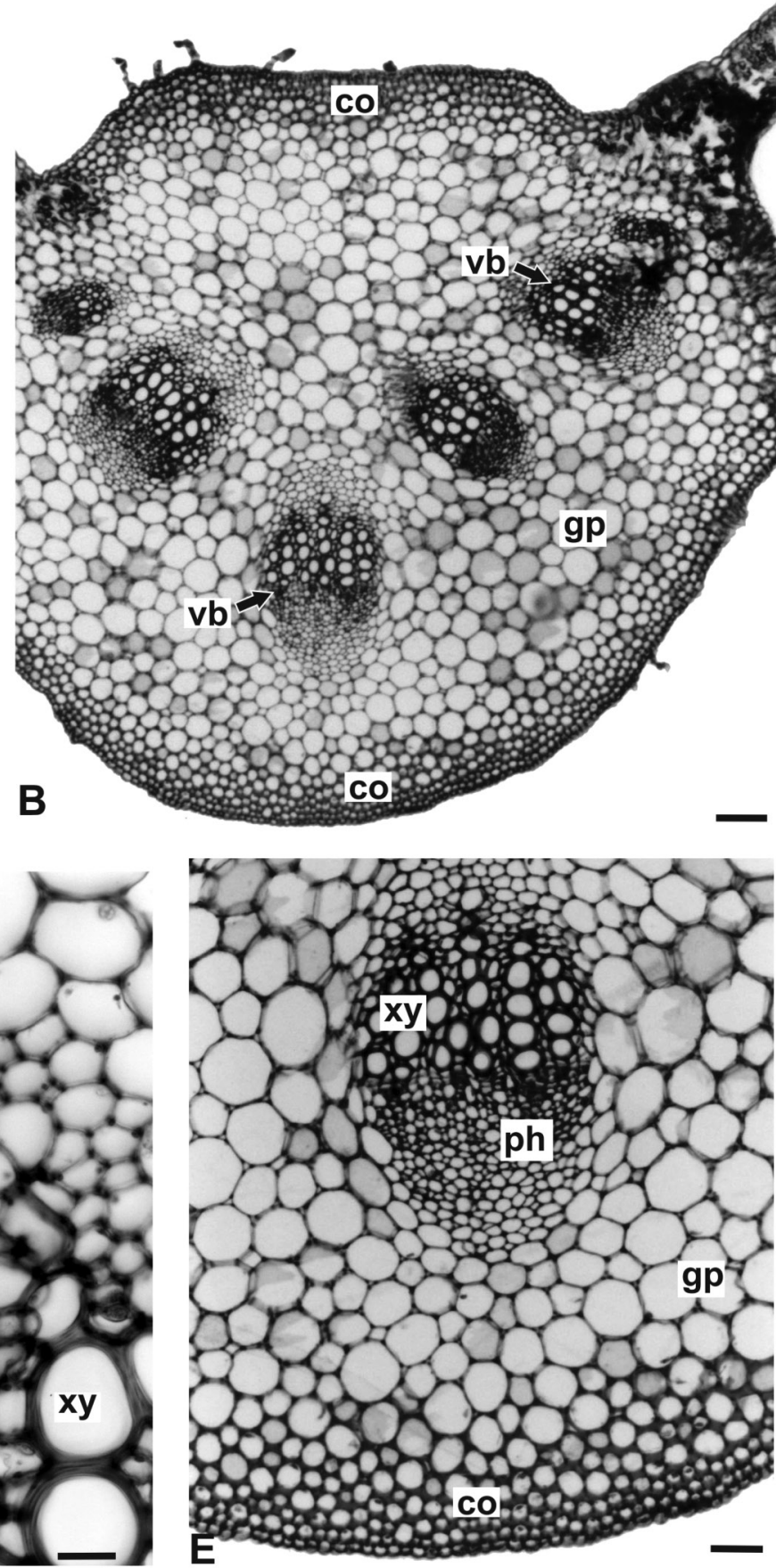

FIGURE 2 - A-E: Gymnanthemum amygdalinum (Delile) Sch.Bip. ex Walp. - leaf, transverse section: A. Interveinal region, showing dorsiventral mesophyll and a minor collateral vascular bundle; B. Midrib organization; C. Detail of a glandular trichome and angular collenchyma of the midrib; D. Calcium oxalate crystal near a vascular bundle; E. Collateral vascular bundle of the midrib. Abbreviations: co - collenchyma, cr - crystal of calcium oxalate, ep - epidermis, gp - ground parenchyma, gt - glandular trichome, $\mathrm{ph}$ - phloem, pp - palisade parenchyma, sp - spongy parenchyma, st - stomatum, vb - vascular bundle, $\mathrm{xy}-\mathrm{xylem}$. $\operatorname{Bar}=100 \mu \mathrm{m}(\mathrm{B}), 50 \mu \mathrm{m}(\mathrm{E}), 20 \mu \mathrm{m}(\mathrm{A}, \mathrm{C}, \mathrm{D})$. 

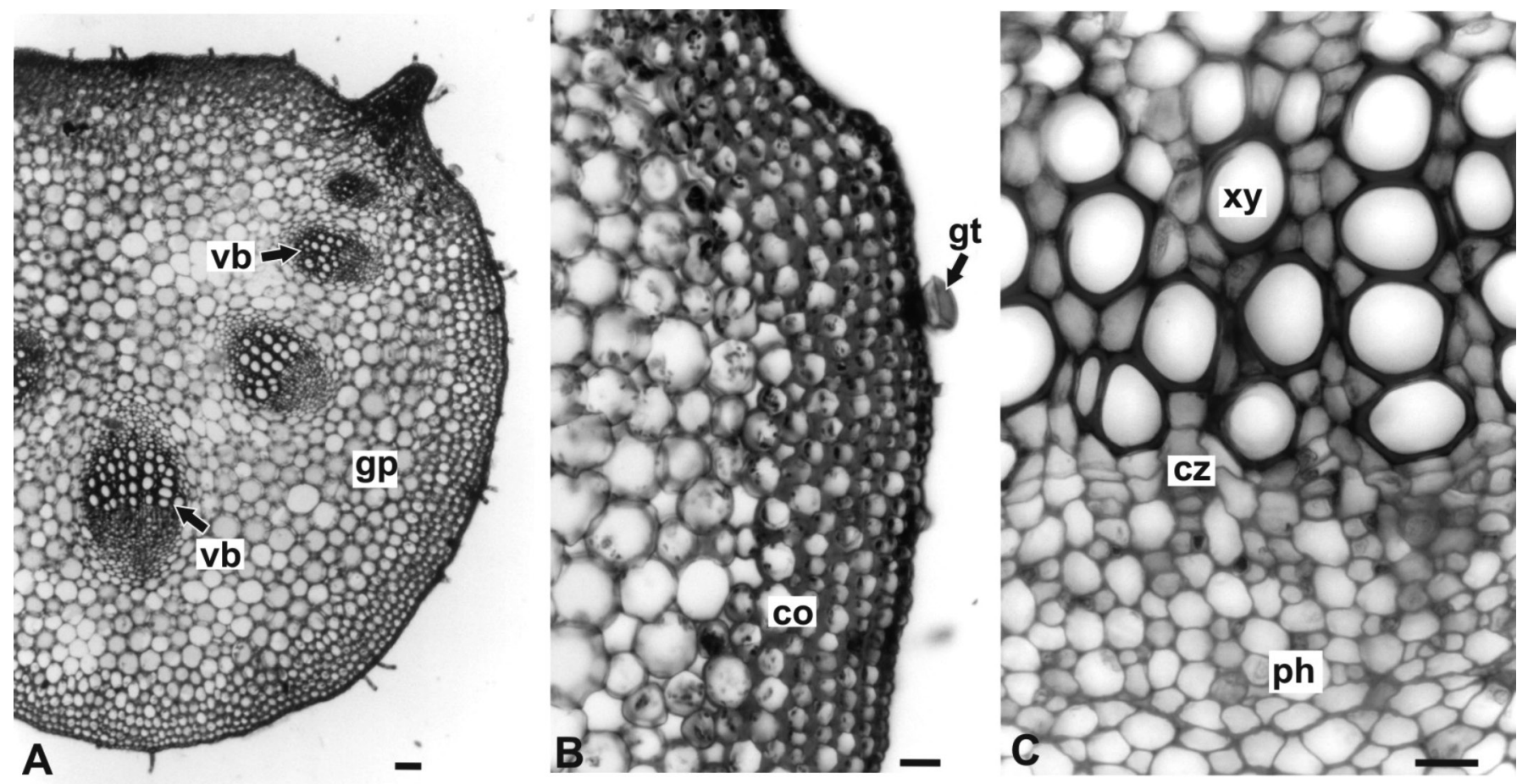

FIGURE 3 - A-C: Gymnanthemum amygdalinum (Delile) Sch.Bip. ex Walp. - petiole, transverse section: A. Overall feature of the petiole; B. Glandular trichome and collenchyma; C. Detail of a collateral vascular bundle. Abbreviations: co - collenchyma, cz cambial zone, gp - ground parenchyma, gt - glandular trichome, ph - phloem, vb - vascular bundle, xy - xylem. Bar = $100 \mu \mathrm{m}(\mathrm{A})$, $20 \mu \mathrm{m}(\mathrm{B}, \mathrm{C})$.

of calcium oxalate, resembling rough druses, are located near some vascular bundles (Figure 2D).

The stem is circular in cross-section. In incipient secondary development, the epidermis is uniseriate and persists, and the phellogen originates just below it (Figure 4C). Glandular and non-glandular trichomes are present as described previously. In the cortex, there are some layers of tangential-angular collenchyma and multiseriate cortical parenchyma (Figures 4A, 4C). The inner boundary consists of a typical endodermis (Figures 4B, 4D). The vascular system is represented by a cylinder of phloem external to the xylem (Figure 4A) and both show straight rays. The xylem is totally lignified and has solitary or small groups of tracheary elements (Figures 4A, 4B). There are sclerenchymatic caps adjoining the phloem (Figures 4A, $4 \mathrm{~B}, 4 \mathrm{D}$ ) and the pith is parenchymatic (Figure 4A).

\section{DISCUSSION}

The Asteraceae family is very large and wellrepresented in a wide range of latitudes and, as would be expected, the anatomical structure of its members shows considerable diversity in correlation with habitat differences, whilst ecological specializations also occur (Metcalfe, Chalk, 1950). In this study, Gymnanthemum amygdalinum displayed features in common to many medicinal species of this family, such as leaf with uniseriate epidermis, dorsiventral mesophyll, simple arc of collateral vascular bundles in the midrib and petiole, as well as stem with peripheral development of the phellogen, outer cortex consisting of collenchyma, well defined endodermis and crescent-shaped strands of sclerenchyma at the outer boundary of the phloem.

However, some aspects concerning trichomes, cuticle characters, patterns and occurrence of stomata on the leaf surface are of considerable taxonomic value and may help to distinguish one species from another (Metcalfe, Chalk, 1950; 1988).

Due to lack of anatomical data on the genus Gymnanthemum, comparisons should be made with related taxa. In this case, with species of Vernonia, since G. amygdalinum was formerly circumscribed to this taxon. According to Adedeji and Jewoola (2008), Vernonia spp. have T-shaped or flabelliform trichomes as a delimiting character. These types of appendage were not seen in this investigation and contribute to support the taxonomic repositioning of $G$. amygdalinum.

Comparatively with close species, the presence of flagelliform trichomes and biconvex midrib mentioned in Vernonia scorpioides (Lam.) Pers. by Toigo et al. (2004) 

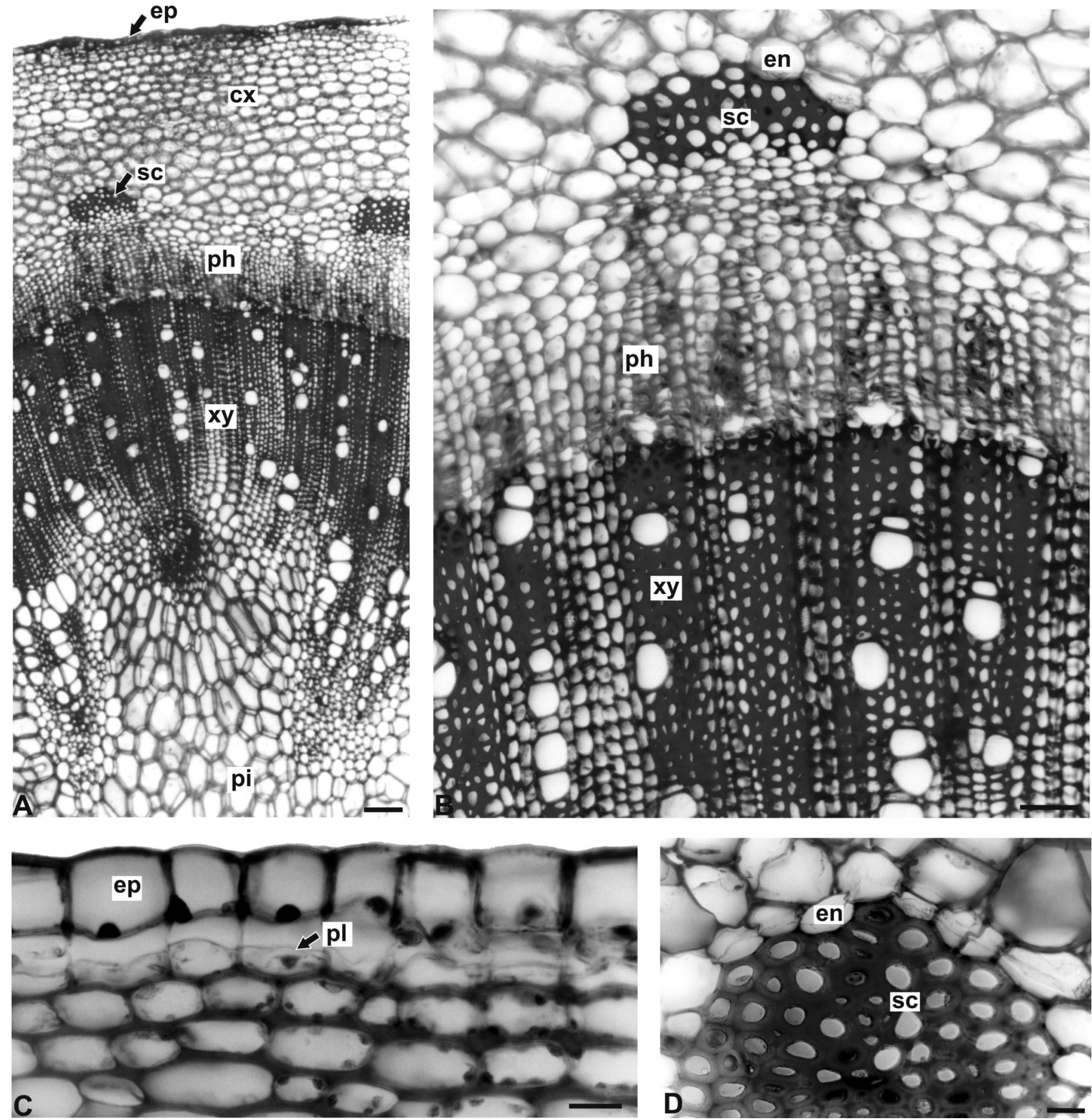

FIGURE 4 - A-D: Gymnanthemum amygdalinum (Delile) Sch.Bip. ex Walp. - stem, transverse section: A. Overall organization; B. Detail of the vascular cylinder; C. Phellogen development; D. Detail of the endodermis and a sclerenchymatic cap. Abbreviations: cx - cortex, en - endodermis, ep - epidermis, ph - phloem, pi - pith, pl - phellogen, sc - sclerenchymatic cap, xy - xylem. $\mathrm{Bar}=100 \mu \mathrm{m}(\mathrm{A}), 50 \mu \mathrm{m}(\mathrm{B}), 20 \mu \mathrm{m}(\mathrm{C}, \mathrm{D})$.

can be considered leaf structures that are distinct from the species examined herein. Concerning the stem anatomy, both species are alike.

With reference to the work that focused exclusively on leaf epidermal features (Oladele, 1990), Vernonia cinerea (L.) Less. exhibited regular T-shaped trichomes, with a long apical cell attached centrically to a uniseriate stalk, which were neither observed in G. amygdalinum by Oladele (1990) nor in this survey.

Vernonia condensata Baker differs from $G$. 
amygdalinum, as the former has hypostomatic leaf and biconvex midrib in cross-section as claimed by Lolis and Milaneze-Gutierre (2003). However, controversial data was reported by Milan, Hayashi and Apezzato-da-Glória (2006), authors who stated that the leaf of $V$. condensata is amphistomatic.

Relying on the investigation by Filizola et al. (2003), Vernonia brasiliana (L.) Druce exhibited hypostomatic leaf, T-shaped trichomes, biconvex midrib, circular petiole and stem with notable sinuous contour in cross-section. None of these aspects or the previous ones referring to Vernonia species were found in this research and therefore may be viewed as diagnostic markers among the compared species.

Nevertheless, as is well known, some structures may be modified as response to environmental influences. Corroborating this statement, Eltahir and AbuEReish (2011) concluded that G. amygdalinum grown in relatively dry places in Africa showed thick cuticle and sunken stomata on both epidermal surfaces as adaptations to minimize the loss of water. These features were not found in this study and should not be taken into account for identification of the species.

Thus, on the basis of these comparisons, the main aspects that characterize G. amygdalinum are stomata on both leaf surfaces, midrib and petiole features, typical endodermis and sclerenchymatic caps in the stem, as well as the trichome peculiarities on both aerial organs. These anatomical characters, considered together, are relevant for the correct identification of this medicinal species for pharmacognostic purposes.

\section{ACKNOWLEDGEMENTS}

The species voucher was registered at the Museu Botânico Municipal de Curitiba and scanning electron micrographs were performed at the Centro de Microscopia Eletrônica da Universidade Federal do Paraná.

\section{REFERENCES}

ACHIGAN-DAKO, E.; PASQUINI, M.; ASSOGBAKOMLAN, F.; SOGNIGBÉ, N.; DANSI, A.; AMBROSEOJI, B. Traditional vegetables of Benin: diversity, distribution, ecology, agronomy, and utilisation. Bangor: IFS, 2009. $252 \mathrm{p}$.

ADEDEJI, O.; JEWOOLA, O.A. Importance of leaf epidermal characters in the Asteraceae family. Not. Bot. Hort. Agrobot. Cluj., v.36, n.2, p.7-16, 2008.
ADEMOLA, I.O.; ELOFF, J.N. Anthelminthic activity of acetone extract and fractions of Vernonia amygdalina against Haemonchus contortus eggs and larvae. Trop. Anim. Health Prod., v.43, n.2, p.521-527, 2011.

ADIUKWU, P.C.; AMON, A.; NAMBATYA, G. Pharmacognostic, antiplasmodial and antipyretic evaluation of the aqueous extract of Vernonia amygdalina leaf. Int. $J$. Biol. Chem. Sci., v.5, n.2, p.709-716, 2011.

AGRA, M.F.; SILVA, K.N.; DINIZ, I.J.L.; FREITAS, P.F.; BARBOSA-FILHO, J.M. Survey of medicinal plants used in the region Northeast of Brazil. Rev. Bras. Farmacogn., v.18, n.3, p.472-508, 2008.

AJIBOLA, C.F.; ELEYINMI, A.F.; ALUKO, R.E. Kinetics of the inhibition of renin and angiotensin I converting enzyme by polar and non-polar polyphenolic extracts of Vernonia amygdalina and Gongronema latifolium leaves. Plant Foods Hum. Nutr., v.66, n.4, p.320-327, 2011.

AKINOLA, O.B.; OMOTOSO, G.O.; AKINOLA, O.S.; DOSUMU, O.O.; ADEWOYE, E.T. Effects of combined leaf extract of Vernonia amygdalina and Azadirachta indica on hepatic morphology and hepatotoxicity markers in streptozotocin-induced diabetic rats. J. Chin. Integr. Med., v.9, n.12, p.1373-1379, 2011.

ALMEIDA, C.F.C.B.R.; RAMOS, M.A.; SILVA, R.R.V.; MELO, J.G.; MEDEIROS, M.F.T.; ARAÚJO, T.A.S.; ALMEIDA, A.L.S.; AMORIM, E.L.C.; ALVES, R.R.N.; ALBUQUERQUE, U.P. Intracultural variation in the knowledge of medicinal plants in an urban-rural community in the atlantic forest from northeastern Brazil. Evid.-Based Compl. Alt., v.2012, 15 p., 2012.

ATANGWHO, I.J.; EBONG, P.E.; EYONG, E.U.; WILLIAMS, I.O.; ETENG, M.U.; EGBUNG, G.E. Comparative chemical composition of leaves of some antidiabetic medicinal plants: Azadirachta indica, Vernonia amygdalina and Gongronema latifolium. Afr. J. Biotechnol., v.8, n.18, p.4685-4689, 2009.

BABALOLA, O.O.; ANETOR, J.I.; ADENIYI, F.A. Amelioration of carbon tetrachloride-induced hepatotoxicity by terpenoid extract from leaves of Vernonia amydgalina. Afr. J. Med. Med. Sci., v.30, n.1/2, p.91-93, 2001.

BERLYN, G.P.; MIKSCHE, J.P. Botanical microtechnique and cytochemistry. Ames: Iowa State University Press, 1976. $326 \mathrm{p}$. 
COELHO-FERREIRA, M. Medicinal knowledge and plant utilization in an Amazonian coastal community of Marudá, Pará State (Brazil). J. Ethnopharmacol., v.126, n.2, p.159$175,2009$.

ELTAHIR, A.S.; ABUEREISH, I. Microscopical studies on the leaf and petiole of Vernonia amygdalina Del. Adv. Appl. Sci. Res., v.2, n.2, p.398-406, 2011.

ERASTO, P.; GRIERSON, D.S.; AFOLAYAN, A.J. Bioactive sesquiterpene lactones from the leaves of Vernonia amygdalina. J. Ethnopharmacol., v.106, n.1, p.117-120, 2006.

FAROMBI, E.O.; OWOEYE, O. Antioxidative and chemopreventive properties of Vernonia amygdalina and Garcinia biflavonoid. Int. J. Environ. Res. Public Health, v.8, n.6, p.2533-2555, 2011.

FILIZOLA, L.R.S.; PIMENTEL, R.M.M.; RANDAU, K.P.; XAVIER, H.S. Anatomia dos órgãos vegetativos de Vernonia brasiliana (L.) Druce. Lat. Am. J. Pharm., v.22, n.4, p.299-303, 2003.

FOSTER, A.S. Practical plant anatomy. New York: D. Van Nostrand, 1949. 228 p.

GEORGEWILL, O.A.; GEORGEWILL, U.O. Evaluation of the anti-inflammatory activity of extract of Vernonia amygdalina. Asian Pac. J. Trop. Med., v.3, n.2, p.150-151, 2010 .

IGILE, G.O.; OLESZEK, W.; JURZYSTA, M.; BURDA, S.; FAFUNSO, M.; FASANMADE, A.A. Flavonoids from Vernonia amygdalina and their antioxidant activities. $J$. Agric. Food Chem., v.42, n.11, p.2445-2448, 1994.

JOHANSEN, D.A. Plant microtechnique. New York: McGrawHill Book, 1940. 523 p.

LOLIS, M.I.G.A.; MILANEZE-GUTIERRE, M.A. Morfoanatomia das folhas de Vernonia condensata Baker (Asteraceae), o "figatil". Rev. Bras. Farmacogn., v.13, suppl.1, p.68-71, 2003.

LUO, X.; JIANG, Y.; FRONCZEK, F.R.; LIN, C.; IZEVBIGIE, E.B.; LEE, K.S. Isolation and structure determination of a sesquiterpene lactone (vernodalinol) from Vernonia amygdalina extracts. Pharm. Biol., v.49, n.5, p.464-470, 2011.
METCALFE, C.R.; CHALK, L. Anatomy of the dicotyledons: leaves, stem, and wood in relation to taxonomy, with notes on economic uses. Oxford: Clarendon, 1950. v.2, 1500 p.

METCALFE, C.R.; CHALK, L. Anatomy of the dicotyledons: systematic anatomy of the leaf and stem. Oxford: Clarendon, 1988. v.1, 276 p.

MILAN, P.; HAYASHI, A.H.; APEZZATO-DA-GLÓRIA, B. Comparative leaf morphology and anatomy of three Asteraceae species. Braz. Arch. Biol. Technol., v.49, n.1, p.135-144, 2006.

MOMOH, M.A.; MUHAMED, U.; AGBOKE, A.A.; AKPABIO, E.I.; OSONWA, U.E. Immunological effect of aqueous extract of Vernonia amygdalina and a known immune booster called immunace and their admixtures on HIV/ AIDS clients: a comparative study. Asian Pac. J. Trop. Biomed., v.2, n.3, p.181-184, 2012.

O’BRIEN, T.P.; FEDER, N.; MCCULLY, M.E. Polychromatic staining of plant cell walls by toluidine blue O. Protoplasma, v.59, n.2, p.368-373, 1964.

OKIGBO, R.N.; MMEKA, E.C. Antimicrobial effects of three tropical plant extracts on Staphylococcus aureus, Escherichia coli and Candida albicans. Afr. J. Tradit. Complement. Altern. Med., v.5, n.3, p.226-229, 2008.

OLADELE, F.A. Leaf epidermal features in Vernonia amygdalina and Vernonia cinerea. Nigerian J. Bot., v.3, n.0, p.71-77, 1990 .

OLIVEIRA, F.; AKISUE, G. Fundamentos de farmacobotânica. São Paulo: Atheneu, 1997. 178 p.

ONG, K.W.; HSU, A.; SONG, L.; HUANG, D.; TAN, B.K.H. Polyphenols-rich Vernonia amygdalina shows antidiabetic effects in streptozotocin-induced diabetic rats. $J$. Ethnopharmacol., v.133, n.2, p.598-607, 2011.

ROESER, K.R. Die Nadel der Schwarzkiefer-Massenprodukt und Kunstwerk der Natur. Mikrokosmos, v.61, n.2, p.3336,1972 .

SALIU, J.A.; ADEMILUYI, A.O.; AKINYEMI, A.J.; OBOH, $\mathrm{G}$. In vitro antidiabetes and antihypertension properties of phenolic extracts from bitter leaf (Vernonia amygdalina Del.). J. Food Biochem., v.36, n.5, p.569-576, 2011. 
SASS, J.E. Botanical microtechnique. Ames: Iowa State College Press, 1951. $228 \mathrm{p}$.

SOUZA, W. Técnicas básicas de microscopia eletrônica aplicadas às Ciências Biológicas. Rio de Janeiro: Sociedade Brasileira de Microscopia Eletrônica, 1998. 179 p.

TADESSE, A.; GEBRE-HIWOT, A.; ASRES, K.; DJOTE, M.; FROMMEL, D. The in vitro activity of Vernonia amygdalina on Leishmania aethiopica. Ethiop. Med. J., v.31, n.3, p.183-189, 1993.
TOIGO, L.; OLIVEIRA, R.F.; OLIVEIRA, F.; MARQUES, M.O.M. Caracterização farmacobotânica, estudo do óleo essencial e atividade antimicrobiana da erva de São Simão - Vernonia scorpioides (Lam.) Pers. Rev. Bras. Farm., v.85, n.2, p.49-55, 2004.

VIGNERON, M.; DEPARIS, X.; DEHARO, E.; BOURDY, G. Antimalarial remedies in French Guiana: a knowledge attitudes and practices study. J. Ethnopharmacol., v.98, n.3, p.351-360, 2005.

Received for publication on $02^{\text {nd }}$ November 2012 Accepted for publication on $02^{\text {nd }}$ September 2013 